\title{
Improving Students' Speaking Skill through Yahoo Messenger at University of Iqra Buru
}

\author{
Saidna Zulfiqar A. Bin Tahir \\ English Education Department, the Faculty of Teacher Training and Education, University of Iqra Buru, Ambon, Indonesia
}

\section{Email address:}

saidnazulfiqar@gmail.com

\section{To cite this article:}

Saidna Zulfiqar A. Bin Tahir. Improving Students' Speaking Skill through Yahoo Messenger at University of Iqra Buru. International Journal of Language and Linguistics. Vol. 3, No. 3, 2015, pp. 174-181. doi: 10.11648/j.ij11.20150303.20

\begin{abstract}
The objectives of research were: (1) to find out whether or not the use of Yahoo Messenger (YM) improves the students' speaking skill, and (2) to find out whether or not the students are interested in joining speaking class. This research employed Quasi Experimental Time Series Design. The sample consisted of 15 students of second semester of English Department of University of Iqra Buru in academic year 2012/2013. The data were collected through three kinds of instruments: speaking test to obtain data of students' speaking skill, questionnaire to obtain data of students' interest, and observation to obtain data of students' activeness in joining speaking class. Data on students' speaking skill were analyzed using descriptive and inferential statistics, data on students' interest were analyzed using Likert scale, and observation data were analyzed descriptively. The results of the research were: (1) the use of Yahoo Messenger in teaching speaking improved the students speaking skill; (2) the use of Yahoo Messenger increased the students' interest in joining speaking class. It can be concluded that the use of Yahoo Messenger was effective medium to improve the students' speaking skill in terms of accuracy, fluency, and comprehensibility, and YM can increase the students' interest in joining speaking class.
\end{abstract}

Keywords: Speaking Skill, Yahoo Messenger, Interest

\section{Introduction}

Speaking has played an important role in foreign language setting. It was considered to be the undervalued skills. Perhaps this is due to the assumption that the main indicator of success in learning a language is the ability to speak that language. Unfortunately, many students of English Department of University of Iqra Buru (UNIQBU) in Ambon, Indonesia, they cannot communicate with each other in English well, either in the classroom or outside the classroom. Although English has become a compulsory subject in Indonesia from the fourth grade of elementary school up to university level, students are still poor in speaking English.

My first observation shown the poor level of students' speaking skill caused of the low of their activeness and interest in joining English class especially in speaking. It can be proven by their attendance the subject less than $75 \%$; they were frequently passive in practicing their English such in the classroom or outside the classroom. Even though the faculty has made a rule that was standard on the use of English at faculty and some area of campus which was categorized as speaking area; they were inactiveness to discuss the subject using English; they have difficulty to express their idea in English; they were ashamed to speak and to make mistake when speaking. The main reasons above solely caused of the lack of vocabularies mastered by the students. Besides, the lack of lecturers' ability in teaching English; where they still used conventional method -using speech method and teacher cantered- without giving the chances to the students for practicing; they have no skill to create an interested media of teaching, and they have low ability to use computer and internet as media of teaching even thought the facility was already on campus.

Those phenomenons have become more worried to the faculty and university performance which will produce graduators who have no quality and invaluable in English if the problems wouldn't be solved soon. In order to teach speaking successfully, a teacher should concern about the students' motivation and interest. The use of media, somehow, would help the students to reach the objective of teaching (Hamalik, 1998); (Gerlach and Ely, 1980); (Long 
Van Nguyen, 2010); and (Jie Xiaoping, 2011).

Nowadays, the use of internet was familiar and it has enabled changes in the way of people life, work, interact, and acquiring knowledge and learning. It has increasingly become popular communication tools used by millions of worldwide users at home, at work, and at school. It seems to become favorite supporting tool for real time communication. Most people almost never miss their time to get online every day whether to browse something or to chat with other people using instant Messenger (IM).

Some of previous studies on the field of internet as teaching media shown that the internet can serve as an excellent tool for language acquisition and improving language competences, it also can increase students' interest and motivation and hence learning better through the media when they are relaxed and enjoyable in teaching and learning process (Garret, 1991), (Jaeglin, 1998), (Crolotte, 2005), (Xiao, 2007), and (Lin Shen \& Jitpanat Suwanthep, 2011).

Base on the background above, the researcher implemented a study to enhance students' speaking skill using synchronous Computer Mediated Communication (CMC) namely Instant Messenger (IM) that is Yahoo Messenger (YM), it is a free instant tools provided by Yahoo Inc. to chat via the internet orally and written among people over the world, it was easy to use and free of cost, it was certain can be available as a medium to increase the students' speaking achievement. The researcher convinced that this medium can increase students' interest and motivation in joining English class. Besides, it was easy and enjoyable to use and free of cost, the students also have already registered on YM, so they can log in directly and practice their English orally and written amongst native or non native speakers of English around the world without feeling ashamed, and it is spontaneously will increase their English skill such as listening, speaking, writing, and reading. And this research focused on speaking skill in terms of Accuracy, Fluency, and comprehensibility and also the students' interest.

\section{Method}

This research applied Time-Series Design. It was part of a Quasi-experimental design that involved periodic measurements on the dependent variable for a group of test units. This is a quasi-experiment, because there was no randomization of test units to treatments, and the timing of treatment presentation, as well as which test units are exposed to the treatment, may not be within the researcher's control (Gay, 2006).

\subsection{Sample / Participants}

The population of this research was all the second semester students of English Department at University of Iqra Buru in academic year 2012/2013. There was only one class consisted of 15 students so the total number of population was 15 students. Since the population was absolutely small in number or the total number of sample was 15 students with one class, then all of them have been involved as the samples of this research. This sampling technique by Sugiyono (2010) was called by Census Sampling Technique.

\subsection{Instrument(s)}

The researcher used three kinds of instruments namely speaking test, questionnaire and observation. The kind of speaking test in this research was transactional dialogue that has been conducted in pretests and posttests. The pretest was administered repeatedly before applying the Yahoo Messenger voice chat program. On the other hand, the posttest was administered repeatedly after applying the materials and the application of the Yahoo Messenger voice chat. The test was developed based on the curriculum of Language and Literature Faculty at UNIQBU. This research has been conducted outside the hours of lectures or it has been implemented by using the extra time. The questionnaire in this research has been given to find out the students' interest toward the application of Yahoo Messenger voice chat. The questionnaire of students' interest was measured using Likert Scale. The questionnaire was distributed to the students after the treatments. Beside those two instruments, the researcher also used observation to see the improvement of students' behavior in ongoing processes of treatments of time series design.

Before conducting the treatment, a group has been administered pre-tests repeatedly until pre-tests score are stable; than the group was exposed to treatments and after treatment implementation, repeatedly post-tested then giving a questionnaire to know the students' interest. If a group score essentially the same on a number of pre-test and the significantly improves following a treatment, the research can be more confident about the effectiveness of the treatment than if just one pre-test and one post test were administered (Creswell, 2008). In this research, the researcher intended to use interrupted time series which examined difference scores between the pretests and posttests. On the other hand, the score in pretest Seri 1 will be compared with posttest 1 , pretest Seri 2 with posttest 2, pretest Seri 3 will be compared with posttest 3, and pretest 4 will be compared to pretests 4 , then pretests series and posttests will be processed and analyzed to answer research questions and test the research hypothesis is accepted or rejected.

\subsection{Data Analysis}

The Data on students' speaking and questionnaire were collected in line with the instruments (test and questionnaire), it will be scoring, converting, classifying, and calculating. In calculating the t-test value (at the significant level 0.05) and consulting t-table value to see the difference between pretests and posttests in a group, the researcher also used SPSS program version 17.0. The data of questionnaire has been analyzed using Likert Scale and then analyzed in percentage to see the students' interest toward Yahoo Messenger voice chat in teaching speaking. In this case, the students' interest 
was categorized into positive and the negative statement.

\section{Results}

The hypotheses were tested using inferential analysis. In this case, the researcher used t-test (testing of significance) or paired samples test for independent sample test, that is, a test to know the significance of difference between the result of students' mean scores in all mean score of pre-tests and post tests.

Assuming that the level of significance $(\alpha)=0.05$, the only thing which is needed; the degree of freedom $(\mathrm{df})=15$, where N1 - $1=14$ is 2.145 . This means that if the result of computed t-test is less or same as 2.145, $\mathrm{H}_{0}$ (Null Hypothesis) is accepted. In contrast, if the result of t-test is more than 2.145, $\mathrm{H}_{0}$ is rejected. Below are the T-Test results in all series in term of accuracy, fluency, and comprehensibility:

Table 1. The Probability Value of T-Test of the Students'Achievement on Pretests and Post tests in Term of Accuracy, Fluency, and Comprehensibility.

\begin{tabular}{|c|c|c|c|c|}
\hline & $\mathbf{T}$ & $\begin{array}{l}2 \text { Tailed } \\
\text { Value }\end{array}$ & $(\alpha)$ & Remarks \\
\hline $\begin{array}{l}\text { Pre-tests and Post tests } \\
\text { (Accuracy) }\end{array}$ & 11.675 & 0.00 & 0.05 & $\begin{array}{l}\text { Significantly } \\
\text { Different }\end{array}$ \\
\hline $\begin{array}{l}\text { Pre-tests and Post tests } \\
\text { (Fluency) }\end{array}$ & 11.660 & 0.00 & 0.05 & $\begin{array}{l}\text { Significantly } \\
\text { Different }\end{array}$ \\
\hline $\begin{array}{l}\text { Pre-tests and Post tests } \\
\text { (Comprehensibility) }\end{array}$ & 13.860 & 0.00 & 0.05 & $\begin{array}{l}\text { Significantly } \\
\text { Different }\end{array}$ \\
\hline
\end{tabular}

Based on the result of data analysis as summarized in table 1 , on pre-tests and post tests in term of accuracy, fluency, and comprehensibility, the researcher found that the Probability value (0.00) was smallest than the level of significance at $t$ table (0.05) and the degree of freedom 14. The data also showed that the probability value was smaller than $\alpha$ $(0.00<0.05)$. It indicated that the alternative hypothesis $\left(\mathrm{H}_{1}\right)$ was accepted and the null hypothesis $\left(\mathrm{H}_{0}\right)$ was rejected. In the other word, there was highest significant difference between the students' speaking skill in pre-tests and post tests after the treatment given. Below is the T-Test result as whole as pre-tests and post tests:

Table 2. The Probability Value of T-Test of the Students' Achievement in All Series of Pre-tests and Post tests.

\begin{tabular}{lllll}
\hline & T & $\begin{array}{l}\text { 2 Tailed } \\
\text { Value }\end{array}$ & $(\boldsymbol{\alpha})$ & Remarks \\
\hline $\begin{array}{l}\text { All Pre-tests } \\
\text { and Post tests }\end{array}$ & 18.992 & 0.00 & 0.05 & $\begin{array}{l}\text { Significantly } \\
\text { Different }\end{array}$ \\
\hline
\end{tabular}

The result of data analysis as summarized in table 2 on pre-tests and post tests show the Probability value (0.00) was smallest than the level of significance at t-table (0.05) and the degree of freedom 14 . The data also showed that the probability value was smaller than $\alpha(0.00<0.05)$. It indicated that the alternative hypothesis $\left(\mathrm{H}_{1}\right)$ was accepted and the null hypothesis $\left(\mathrm{H}_{0}\right)$ was rejected. In the other word, there was highest significant difference between the students' speaking skill in pre-tests and post tests after the treatment. It means that the application of Yahoo Messenger in teaching speaking can increase the students' speaking skill, but the most that can be increased was comprehensibility because of students' habitation in communicating with native or non native speakers of English that might help them to understand the speakers' intention. The whole result of students' score in term of accuracy, fluency, and comprehensibility can be seen in the following Figure 1.

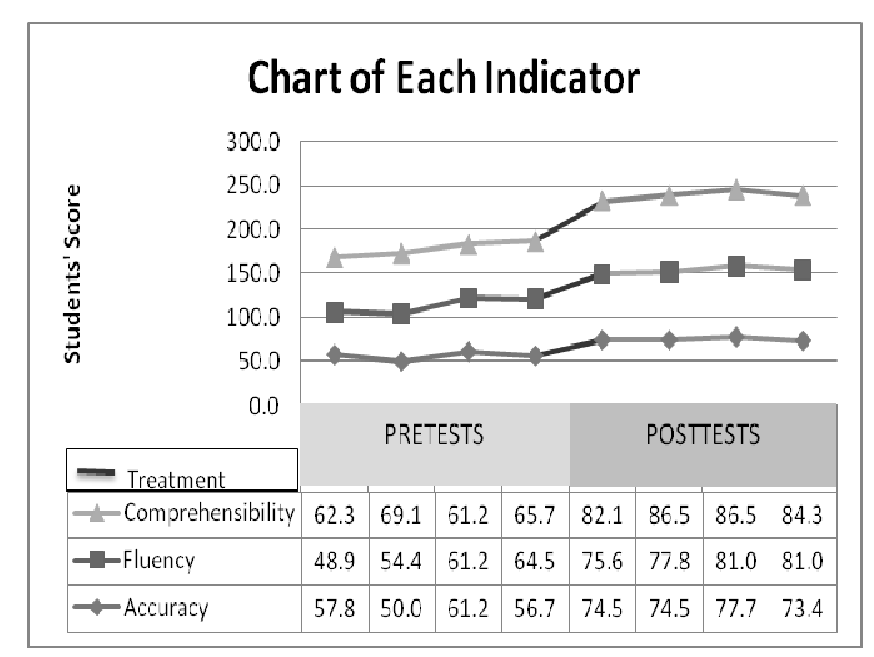

Figure 1. Students' Achievement in Pre-tests and Post tests (Seri 1, 2, 3, 4) in Term of Accuracy, Fluency, and Comprehensibility.

The figure shows that the comprehensibility in all post test was higher than the scores in pre-tests. It means that there was significance different between pre-tests without treatment and post tests after treatment through YM. Those scores were used to analyze whole of students' achievement in speaking which can be seen in the figure 2 below:

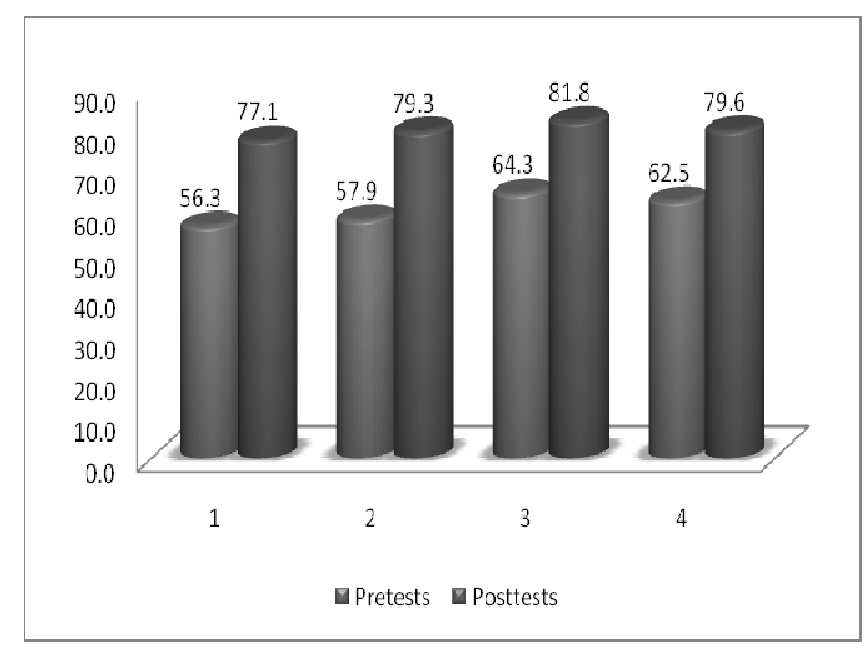

Figure 2. Students' Speaking Achievement in Pre-tests and Post tests in Seri $1,2,3$, and 4 .

Based on the result of data analysis as summarized in Figure 2 on pre-tests and post tests of Time Seri Design (Seri $1,2,3$, and 4 ), the graphic could be made as the following. 


\section{Time Series}

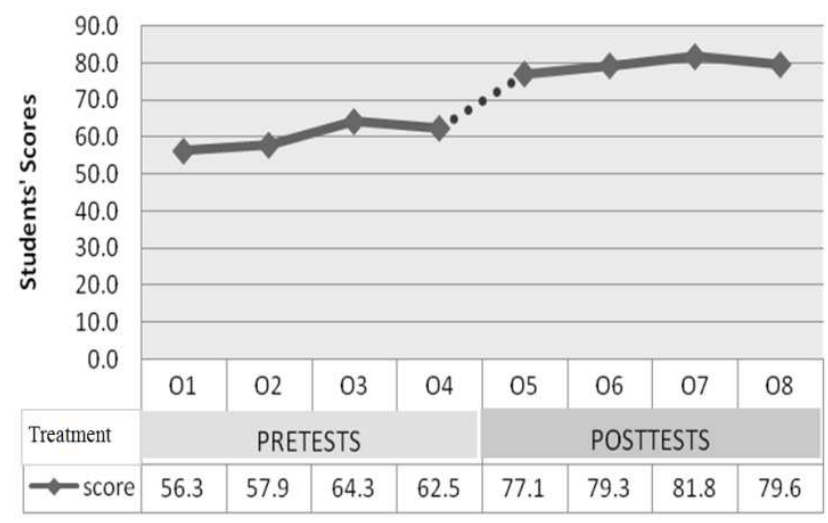

Figure 3. Time Seri Design Graphic.

The students score in post test 1,2 , and 3 shown the students' scores go through the improvement from Seri to Seri. In the last Seri shown that the students' score goes through decreasing caused of the boredom of voice chat while there were many facilities provided by Yahoo Messenger may be used to avoid from the students' saturation in learning that will become a note for the teacher and next researchers that will conduct teaching through YM.

The questionnaires were distributed to the students to know their interest toward Yahoo Messenger in teaching speaking at English Department of University of Iqra Buru. The students' score interval of questionnaires can be shown in table 3.

Table 3. The Percentage of the Students' Interest toward Yahoo Messenger.

\begin{tabular}{llll}
\hline \multirow{2}{*}{ Interval Score } & Category & \multicolumn{2}{l}{ Interest toward Yahoo Messenger } \\
\cline { 3 - 4 } & & F & \% \\
\hline $80-100$ & Very high & 12 & 88.0 \\
$60-79.99$ & High & 3 & 12.0 \\
$40-59.99$ & Moderate & 0 & 0 \\
$20-39.99$ & Low & 0 & 0 \\
Total & & 15 & 100 \\
\hline
\end{tabular}

The data of the students' interval score based on the questionnaire in table 3 indicates that the use of Yahoo Messenger in teaching speaking was very interested, it shown that 12 students (88.0 percent) felt strongly positive, 3 students ( 20 percent) of the students felt positive, and none of the students felt neutral, negative and strongly negative. Further analysis showed that the mean score of Yahoo Messenger was 88.00 which were categorized as very high interest.

\section{Discussion}

In this research, there are three items that researcher try to find out, they are accuracy (77.66), fluency (81), and comprehensibility (86.43). The highest score was comprehensibility. Comprehensibility in speaking means that people can understand what we say and we can understand what they say. Harmer (1991) says that if two people want to make communication to each other, they have to speak because they have different information. If there is a 'gap' between them, it is not a good communication if the people still confuse with what they say. To avoid from the gap, the speaker should pay attention to the process of constructing meaning. An interactive process of constructing meaning involves producing, receiving and processing information (Burn and Joyce, 1997). Its form and its meaning are dependent on the context in which it occurs, including the participants themselves, their collective experiences, the physical environment, an acceptable level of language, and the purposes for speaking.

The context of speaking tests were familiar for the students, so they have many experiences before, and at least, they have memorized many words related to the topics even though they forgot some words but they can understand the speaker intention through recalling and guessing the meaning based on the context. Beside, the medium was used (YM) here can increase the students' interest so they have good physical environment to speak with native or non native speaker of English without assumed, and without fear to express their ideas and the level of language used was daily conversation that helped students to be easy to understand the speech. It also caused of most of the time were used to speak and it could make them adapted to communicate and understand the meaning and also it made them habitual to speak.

Even though comprehensibility was the highest score but most students get problems in speaking to express their ideas so that the speaker can understand their intention and those caused of inhabitation, lack of vocabularies or nothing to say, and the influence of mother tongue or first language (Ur, 1996). Therefore, to solve students' inhabitation, lack of vocabularies, and mother tongue, the teacher should pay full attention in teaching and learning activities such as monologue, dialogue, question and answer, and speaking game.

Another problem faced by the students in expressing their ideas was pronunciation. Pronunciation is one of the important components that a good English speaker uses when he/she expresses his/her ideas in an interaction in order to have a good communication. In fact, the students made some mistakes in pronouncing some English words. They found it hard to pronounce some English words because mostly they were influenced by the use of their mother tongue. This is in line also with Wenden (1987) said that to be successful in language leaning, one should use the language as often as possible, think with the target language, and live and study in an environment here the target language is spoken. Therefore, to get students' good pronunciation, the teacher should pay attention in teaching and learning process.

Students' score in term of comprehensibility were higher than fluency and accuracy because of fluency and accuracy did not lie totally only on mastering the language system but it also lays on the vocabularies as using the language system communicatively, and without too much hesitation. As 
Richard and Rodgers (2001) stated that fluency is the ability to produce written or spoken language easily. This indicates that spoken language is produced naturally with hurtles. They also added fluency is the ability to speak with a good but necessarily perfect command of intonation, vocabulary and grammar. So the lack of vocabularies and grammar or mastering language system has become hindrances and obstacles for the students to speak fluently and accuratively. That caused of the students have low achievement in fluency and accuracy.

Students' score in term of comprehensibility were higher than fluency and accuracy also caused of medium in teaching. Students were interested to learn speaking through Yahoo Messenger because YM has many facilities that can be used as medium in communication such as orally and written. YM can help the students to communicate with native or nonnative speakers of English around the world. So that, they can learn how to pronounce the words correctly, understanding the speakers intention, and know more several of English dialect in the world. As Ur (1996) has defined characteristic of successful speaking activities are a lot of learner talk, even participation including media, high motivation, and an acceptable level of language. What the students need and want, they can get them through YM.

The students' score in all series show the improvement in term of accuracy, fluency, and comprehensibility numerically, but statistically on the graphic of scores in all series showed there was decreasing or declining of students' achievement in Seri 4 in all sub variables. These caused of two factors, they are; unfamiliar material to the students and the limit of saturation. The lack of knowledge and vocabularies made the students were difficult to express their idea and they got saturation or boredom for joining speaking class because only one medium was used in this research. According to the theory of Heinrich Gossen I (1810-1858) which familiar with" the law of diminishing marginal utility" stated if the fulfilment of a need for the type of goods carried out continuously, the sense of joy and fun at first will seem high, but the longer the pleasure is declining emulate finally reached saturation limit (in Gilarso, 2003).

Based on the research observation, the researcher concluded that the use of one medium of facilities provided by Yahoo Messenger continuously was effective at the first, second, or maybe on third time and in the next time it will be boring. To avoid from the limit of saturation or boredom, a teacher must creative in create learning activities or by mixing two or more facilities that provided by Yahoo Messenger.

Although the students got high score in all Series of post tests in term of accuracy, fluency, and comprehensibility then in pre-tests, it did not mean that they were good to communicate in English or it did not show that they were perfect without any deficiencies and mistakes they have done. So below are the explanations of each indicator of speaking and the students' deficiencies or mistakes made by the students in speaking.

\subsection{The Students' Speaking Skill in Terms of Accuracy}

The use of Yahoo Messenger in teaching speaking gained a better result in students' speaking performance in term of accuracy. It can be seen from the result of post-tests in each component of students' speaking performance in term of accuracy in each Seri of Time Seri Design and compare it with pre-tests. However, it cannot be denied that the second semester students made some mistakes during the process. The mistakes that the students made were exemplified in the following description.

\subsubsection{Mispronunciation}

Pronunciation is one of the important components that a good English speaker uses when he/she expresses his/her ideas in an interaction in order to have a good communication. In fact, the students made some mistakes in pronouncing some English words. They found it hard to pronounce some English words because mostly they were influenced by the use of their mother tongue. This is in line with Wenden (1987) said that to be successful in language leaning, one should use the language as often as possible, think with the target language, and live and study in an environment where the target language is spoken. Therefore, to get students' good pronunciation, the teacher should pay much attention in the teaching and learning process. Some mistake that the students made when pronouncing English words are as below:

1) The substitution of phonemes, as below

a) $/ \theta /$ becomes $/ \mathrm{t} /$. Example: Thank $/ \theta æ \eta \mathrm{k} /$ becomes

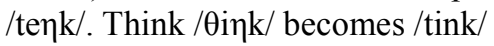

b) /ð/ becomes /d/. Example: Then /ðen/ becomes /den/. They /ðei/ becomes /dei/

2) The omission of consonant cluster, examples are:

a) Next /nekst/ becomes /neks/

b) World /w3:ld/ becomes /word/

3) English words which are pronounced based on the written print. The examples are:

a) Various /væries/ becomes /variuos/

b) Literature /litræce/ becomes /literatur/

The most difficult of pronunciation problems that the students faced were the difficulty to pronounce the phonemes $/ ð, \varnothing /$ either in initial, middle and final position of the words, the consonant cluster /ght, rld/ in the final position. It can be concluded that the students need an active situation where they can practice pronunciation as well. This respect refers to the implementation of Yahoo Messenger voice chat for the students to learn how to pronunciation through their chat partner from native or non-native speakers of English around the world without feeling shy or assumed.

\subsubsection{Grammatical Errors}

Most of the grammatical errors the students made were patterns of syntax, such as: concord, word order, and incomplete sentences. In fact, the researcher found that the students lack of grammar mastery. In making English sentences, they used the Indonesian (L1) system to get the understanding so that they could communicate in English. 
The grammatical errors that the students made can be seen below based on the research data of speaking text script:

1) The misuse of singular and plural nouns.

For example; "I have many hobby, one of them is singing."

It should be "I have many hobbies, one of them is singing."

2) The omission of suffix $-s$ in predicate as the third person singular indicator.

For example; "My father says to me, my name mean 'son' in Arabic."

It should be "My father said to me, my name means 'son' in Arabic."

It can be noted that most of the students still needed more practices to overcome their barriers in grammar. Therefore, during the implementation of teaching learning process, the teacher corrected the students' grammatical errors.

\subsubsection{Inappropriate Word Choice}

The inappropriate use of English words is the words that the students use because of wrong diction, and wrong class of words, the students' mistakes in word choices are as below;

1) Wrong diction. The examples are:

a) "Do you wonna come to visit my hometown?".

It should be "Do you want to come to visit my hometown?"

b) I am gonna be success man.

It should be "I am going to be success man."

2) Wrong class of words. The examples are:

"I want to be an English teaching." It should be "I want to be an English teacher."

It can be noted that the students' mistake in word choice were caused by the lack of English vocabulary and the nonmastery of word usage. Ur (1996: 121) states that some situation to decrease of the problem in accuracy, They are: use group work, base the activity in easy language, make a careful choice topic and task stimulate interest, give some instruction or training in discussion skills, and keep students speaking the target language. From the explanation above can be concluded that Yahoo Messenger voice chat is able to be the solution because it offers almost all solutions explain by Ur.

\subsection{The Students'Speaking Skill in Terms of Fluency}

The researcher found that the lack of students' English vocabulary and the non-mastery of grammar hindered them to speak fluently. They made too many pauses, halting, and repeated words several times. This condition automatically influenced the rhythm of their speaking. They looked stammering so that it fell down their speaking performance. However, in implementing the Yahoo Messenger, the students spoke expressively and bravely. One of the most advantages for the students to use YM is they can ask their partner about the difficult world written while running the dialogue or making voice chat. The students' inhibitions in speaking fluency are as below;

1) Unnatural pauses. It is a pause that the speaker makes when he wants to say something but he loses of words or of the though he wants to express. Example:

a) I like ee.. I like ee.. western music because with western music we can ee...know about character of foreigner.

b) In Jikumarasa beach..we can..ee..we can diving and there we can found ee.. find traditional food

2) Deliberate halting. It is a stop talking and it is because the speaker does not know what to say. Examples:

a) They always come to the place...just for application ee..the internet program..that has ee.. the place provide..the place provided ee..and also..ee....just like that.

b) The place here still nature and...the best view.....I think so sir.

The examples above show that the students' inhibition to speak smoothly, easily, and expressively. And the fact that they tried to look for meaningful expressions always occurred naturally.

\subsection{The Students'Speaking Skill in Terms of Comprehensibility}

The researcher found that the lack of students' English vocabulary and the non-mastery of grammar hindered them to speak fluently and the lack of phrases and idiom mastering that made them misunderstand and misinterpret about the phrases in a sentence. As the result, they did not understand the speakers' intention and on the contrary the speaker did not understand what the students' intention. Some reasons back to the influences of first language (L1) system when they are talking.

a) The lack of students' mastering vocabulary and phrase. For examples:

L: So what should I call you?

RM: Ya?

L: What should I call you?

L: Could you tell me your reason for me why have you chosen this department

RM: What?

L: Explain for me why you chose English department

b) Influencing of first language (L1). For example:

According to me... It should be: In my point of view...

In my opinion, in the era globalization. It should be; In the globalization era.

\subsection{The Students'Interest}

In this study, the interest of the students was considered as output because they were expected to have very high interest category toward the use of Yahoo Messenger in teaching speaking. The students stated that joining the speaking class by using YM could build their interest in learning process. Most of students agree to use YM in teaching speaking class. According to Waejana \& Rzak (2009) Yahoo Messenger is a synchronous communication tool such as chat working in real time and with real people beyond the confines of the classroom. So the students can talk/chat to a lot of people at the same time, they can meet different people with interesting 
characters around the world such as native or non native speakers of English. This increased students' interest toward the medium used in this research.

Yahoo Messenger also can help students to develop others skills that are essential in the active world, such as personal skill (independence or autonomy, interpersonal skills (asking, listening, interviewing, discussing, debating, suggesting, and helping), and organizational skill (setting objectives, time and project management) (Cziko \& Park, 2003). Those advantages of course created an enjoyable, entertaining social learning which gives pleasure to the students. Of course, those benefits made the students more interested in joining the speaking class and automatically influenced the students' achievement.

Comparing with the result of speaking achievement and interest in joining the speaking class using Yahoo Messenger, it shows that this strategy was more effective and useful to increase the students' interest and achievement. It is indicated that the main score speaking achievement in post tests of series were 75.01 which is classified as a good category, while the main score was $88 \%$ which is classified as very high interest. It is in line with Campbell and Dickinson (1996: 17) state that teachers need to incorporate a variety of strategies so that they reach and successful with more students than they have been in the past. It means that teachers should apply various techniques or teaching and learning styles and media to cover the intelligence that occur in the class. It is indicated to avoid students from boredom in learning process.

\section{Conclusions}

Based on the research findings and discussion above, the researcher concluded that the use of Yahoo Messenger in teaching speaking improved the students speaking skill in term of accuracy, fluency, and comprehensibility that is the mean score of the students' post tests in all Series (75.01) are higher than all pre-tests Series (56.43) and also the use of Yahoo Messenger increased the students' interest in joining speaking class.

It is strongly suggested for the teachers to use this medium in teaching English in different skills such as reading, listening and writing that can increase the students' interest in joining the class because of the students can learn English enjoyable and fun through new media that motivated them to study. In conducting research or teaching and learning process through Yahoo Messenger, teachers and next researchers should take into account many aspects of online learning. With more elaborated preparation, more careful monitoring to the places and facilities of computer, timely adjusting of the project, and cost, so greater achievement arising from Yahoo Messenger would be more promising for language teachers and learners.

\section{Acknowledgements}

The research is financed by The Higher Education
Directorate of Indonesia. Thanks for Prof. Haryanto, and Dr. Syarifuddin Dollah, State University of Makassar.

\section{References}

[1] Burns, A \& Heken, Joyce. 1997. Focus on Speaking. Sydney: Macquarie University.

[2] Cambell \& Diction. 1996. Teaching and Learning through Multiple Intelligences. Boston : Ellyn \& Bacon.

[3] Creswell, John, 2008. Educational Research, Planning, Conducting, and Evaluating Quantitative and Qualitative Research, Third Edition. New Jersey, Pearson Prentice Hall.

[4] Crolotte, Mary, Anna, 2005, Improving L2 Oral Proficiency through Online Chatting, UC Davis, University of California.

[5] Garrett. 1991. Technology in the Service of Language Learning: Trends and Issues. Modern Language Journal (online). 75, 74-101. (http://jlls.org/Issues/Volume1/No.2/nazligunduz.pdf, Accessed on 16, 10, 2011).

[6] Gay, L. R. 2006. Educational Research. London : Longman.

[7] Gerlach Vernon, S and D.P Ely. 1980. Teaching and Media: Systematic Approach. New Jersey: Prentice Hall.

[8] Gilarso. 2003. Pengantar Ilmu Ekonomi Mikro (Edisi Revisi). Yogyakarta: Kanisius

[9] Hamalik. 1993. Media Pendidikan. Bandung: PT. Citra Aditya Bakti

[10] Harmers, John. 1991. The Practice of English Language Teaching. London: Longman.

[11] Jaeglin. 1998. Learners' and instructors' attitudes towards computer-assisted class discussion. In J. Swaffar, S. Romano, P. Markley, \& K. Arens. (Eds.), Language Learning Online: Theory and Practice in the ESL and L2 Computer Classroom (pp. 121-138). Austin: Daedalus Group, Inc.

[12] Jie Xiaoping. 2011. E-learning Constructive Role Plays for EFL Learners in China's Tertiary Education, Asian EFL Journal. Professional Teaching Articles - CEBU Issue. Vol. 51 April 2011.

[13] Lin Shen and Jitpanat Suwanthep. 2011. E-learning Constructive Role Plays for EFL Learners in China's Tertiary Education. (Online) Asian EFL Journal. Professional Teaching Articles. Vol. 49 January.

[14] Long Van Nguyen. 2010. Computer Mediated Collaborative Learning within a Communicative Language Teaching Approach: A Sociocultural Perspective. The Asian EFL Journal Quarterly March 2010 Volume 12, Issue 1.

[15] Richards, Jack C. and Theodore, S Rodgers. 2001. Approaches and Methods in Language Teaching. Cambridge: Cambridge University Press.

[16] Sugiyono, 2010, Metode Penelitian Pendidikan, Pendekatan Kuantitatif, Kualitatif, dan R\&D. Bandung. Alfabeta.

[17] Ur. Penny. 1996. A course in Language Teaching Practice and Theory. Cambridge: Cambridge University Press. 
[18] Waejana \& Razaq. 2009. Mudah dan Gampang Menggunakan Yahoo Messenger; Sekali Belajar Langsung Lancar. Penerbit Indah, Surabaya.

[19] Wenden, Anita, 1987. Learner Strategies in Language Learning. Cambridge: Cambridge University Press.
[20] Xiao, Mingly, 2007, An Empirical Study of Using Internetbased Desktop Videoconferencing in an EFL setting" Dissertation, the faculty of the College of Education of Ohio University. 